Journal of Applied Pharmaceutical Science Vol. 4 (10), pp. 038-043, October, 2014

Available online at http://www.japsonline.com

DOI: $10.7324 / \mathrm{JAPS} .2014 .401007$

ISSN 2231-3354 (cc) BY-NC-SA

\title{
Evaluation of Capsicum frutescens powder effects on the growth performances, biochemical and hematological parameters in Hubbard broiler
}

\author{
T. J. Dougnon, P. Kiki, T. V. Dougnon*, I. Youssao \\ Laboratoire de Recherche en Biologie Appliquée (LARBA), Ecole Polytechnique d'Abomey-Calavi, Université d'Abomey-Calavi, Abomey-Calavi.
}

\begin{tabular}{l} 
ARTICLE INFO \\
\hline Article history: \\
Received on: $28 / 05 / 2014$ \\
Revised on: $04 / 07 / 2014$ \\
Accepted on: $18 / 08 / 2014$ \\
Available online: $30 / 10 / 2014$ \\
\hline Key words: \\
Capsicum frutescens, growth \\
performances, biochemical \\
parameters, hematological \\
parameters, broiler Hubbard.
\end{tabular}

\section{INTRODUCTION}

Food security is a major challenge that emerging countries must overcome. For satisfying populations' needs in animal products according to demographic growth, the production of these countries will have to be more than 100 billion tons of meat in 2020 (Laurenson, 2002). Then, in order to ensure food security of rural and urban populations, new programs of livestock development are moving towards the promotion of short-cycle species in general and poultry in particular. In this dynamic, poultry plays a major role in animal production. Indeed, the poultry industry represents an additional source of income in and in many cases an emergency fund. Nevertheless, it is clear that this breeding is confronted with several constraints that lead to high

\footnotetext{
* Corresponding Author

Email: victorien88@hotmail.com
}

mortality rate $(65-70 \%)$ between 0 and 2 months old and fall of zootechnical performance (Laurenson, 2002). Among these constraints, those related to food occupy a prominent place. To face out these constraints, farmers are often used antibiotic growth promoters. These growth promoters are widely used in poultry because of their beneficial effects on feed conversion, growth and health of animals. However, apart from their high cost, these molecules have potential risks of microbial resistance and can have harmful effect on human health (Barreto et al., 2008). It is therefore important to find an endogenous alternative to replace these products. In this regard, there is increasing interest for the use of natural products such as plants, spices and plant extracts in animal feed (Hernandez et al., 2004). According to (Barreto et al. (2008), the plants are well known for their pharmacological effects and plant extracts are used in animal feed as stimulants of appetite, digestion and physiological functions. 
They can also be used for the prevention and treatment of certain diseases and also as colorants and antioxidants. Red bird pepper, Capsicum frutescens, is one of the most plants, which are worldwide used as a spice in food. Its principal constituent is capsaicin. This component gives it several pharmacological properties especially against obesity, hyperglycemia and pain (Chaiyasit et al., 2009). The fruit of Capsicum frutescens also has anti-oxidant properties. Despite studies of Li et al. (2012) on the positive effect of $C$. frutescens on weight gain and improving the color of egg yolk, there is a gap to fill in terms of the benefits of this plant in broiler. This justify the present study which aims to evaluate the effects of Capsicum frutescens powder on growth and some physiological parameters constant in Hubbard broiler.

\section{MATERIAL AND METHODS}

\section{Study environment}

This experiment was carried out for a period of 56 days at Agricultural Research Centre of Agonkanmey of the Benin National Institute of Agricultural Research (INRAB). The chickens were reared on a litter of shavings in pens grid of $2 \mathrm{~m} \mathrm{x}$ $1.5 \mathrm{~m}$. Each pen was equipped with a manger and a drinking trough.

\section{Material}

\section{Diet used}

For this experiment, a starter diet (18\% protein and 2750 $\mathrm{kcal} \mathrm{ME} / \mathrm{kg}$ ) have been used until 28 days of age and a finisher diet $(16 \%$ protein and $2900 \mathrm{kcal} \mathrm{ME} / \mathrm{kg}$ ) from 29 days until 56 days of age. The raw materials used for the preparation of these foods are corn, soybean meal, wheat bran, fish meal, oyster shells, the salt and Vitamin-mineral concentrat flesh 5\%. Fed was made according to the formulation shown in Table 1.

Table 1: Basal diets formulations

\begin{tabular}{lll}
\hline \multirow{2}{*}{ Ingredients } & Percentage (\%) & \\
\cline { 2 - 3 } & starter diet & $\begin{array}{l}\text { finisher } \\
\text { diet }\end{array}$ \\
\hline Corn & 59,7 & 60,7 \\
wheat bran & 7 & 10 \\
Soybean meal & 18 & 16 \\
Oyster shell & 2 & 2 \\
Fish meal & 8 & 6 \\
Vitamin-mineral concentrat $\mathrm{C}_{5}$ & 5 & 5 \\
Salt & 0,3 & 0,3 \\
\hline
\end{tabular}

The capsicum used was purchased on the local market and powdered with an electronic grinder (Retsch GmbH 5657 HAAN) at the Faculty of Agricultural Sciences (FSA) of the University of Abomey-Calavi.

\section{Laboratory equipment}

Tow electronic scale (Weiheng ${ }^{\circledR}:$ Max $7 \mathrm{~kg}, \mathrm{~d}=1 \mathrm{~g}$ and $\mathrm{KERN}^{\circledR}$ : $\max 220 \mathrm{~g}, \mathrm{~d}=0.1 \mathrm{mg}$ ) were used for different weighing (animals, food served and Dry Matter (DM) of food (served and refused). In order to study the carcass characteristics, $\mathrm{pH}$ was measured with a pH-meter (Hanna Instruments Inc., model HI99161). A colorimeter (Minolta chromameter CR-400 (Japan)
CR 400) was used to measure the color of the muscle. A texture analyzer, LF plus (LLOYD Instruments) equipped with a blade with $0.42 \mathrm{~cm}$ of thickness (type Warner-Bratzler) was used to determine the shear force. A bain-marie (Memmert $\mathrm{GmbH}+\mathrm{Co}$, GK, Germany) was used to cook meat.

\section{Methods}

\section{Phytochemical screening of $C$. frutescens powder}

Phytochemical screening was performed at Laboratory of Study and Research in Applied Chemicals (LERCA) of Polytechnic School of Abomey-Calavi (EPAC), Abomey-Calavi, University to identify the main chemical constituents of the powder of Capsicum frutescens. This screening was performed following the protocol described by Houghton and Raman (1998). The following main chemical constituents are sought: anthocyanins, alkaloids, free and combined anthraquinones , flavonoids, catechin and gallic tannins, mucilage, the saponins, reducing compounds, leuco - anthocyanins , coumarins, sterols and polyterpenes.

\section{Evaluation of zootechnical parameters}

The study involved a total of 200 (Hubbard) day old broilers. They had an average weight of $49.63 \pm 3.74 \mathrm{~g}$ and were raised for 8 weeks. The experimental design used was the complete randomized block with 5 treatments each and 4 repetitions of 10 subjects per treatments. These treatments P0, P5, P5 ', P10 and P10 'with:

$\checkmark$ P0: basal diet (BD) without chili powder (CP)

$\checkmark$ P5: $\mathrm{BD}+0.5 \% \mathrm{CP}$ or $5 \mathrm{~g}(\mathrm{CP}) / \mathrm{kg}$ diet for a month;

$\checkmark$ P5': $\mathrm{BD}+0.5 \% \mathrm{CP}$ for two months ;

$\checkmark$ P10 : BD $+1 \% \mathrm{CP}$ or $10 \mathrm{~g}(\mathrm{CP}) / \mathrm{kg}$ diet for a month

$\checkmark$ P10': $\mathrm{BD}+1 \% \mathrm{CP}$ for two months.

Chickens were fed according to the rationing plan proposed by AlKassie et al. (2011). During the experiment, weekly feed intake was determined. Individual live body weight was recorded every 7 days. The chickens were vaccinated against Newcastle disease, infectious bursal disease and infectious bronchitis. They were treated against coccidiosis with Amprolium ${ }^{\circledR}$ and against helminths with Piperazine citrate ${ }^{\circledR}$. The data collected allowed calculating the following zootechnical parameters

$$
\begin{aligned}
& \text { Individual Feed Intake (FI) } \\
& \text { CI }=\frac{\text { Feed served }- \text { feed refused }}{\text { number of chicken }} \\
& \text { Average Daily. Gain (ADG) } \\
& \text { ADG }=\frac{\text { (Final weight }- \text { Initial weight) }}{\text { period }} \\
& \text { Feed Conversion Ratio (FCR) } \\
& \text { FCR }=\frac{\text { Feed intack }}{\text { Body weight gain }}
\end{aligned}
$$

\section{Evaluation of Dry Mater (DM) digestibility}

It was conducted on a total of twelve (12) chickens from $42^{\text {nd }}$ to $49^{\text {th }}$ day. The chickens were placed in individual cages $(45 \mathrm{~cm} \mathrm{x}$ 
$37.5 \mathrm{~cm} \times 33 \mathrm{~cm})$. Each cage was equipped with a feeder, a drinking trough and a manure collecting device. Droppings were collected per animal and weighed daily. For this digestibility test, three treatments with four replications were applied:

$$
\begin{array}{ll}
\checkmark & \text { P0: basal diet (BD ) without chili powder (CP) } \\
\checkmark & \text { P5: } \mathrm{BD}+0.5 \% \mathrm{CP} \text { or } 5 \mathrm{~g}(\mathrm{CP}) / \mathrm{kg} \text { diet; } \\
\checkmark & \text { P10: } \mathrm{BD}+1 \% \mathrm{CP} \text { or } 10 \mathrm{~g}(\mathrm{CP}) / \mathrm{kg} \text { diet. }
\end{array}
$$

The food distributed by cage and the cage refusal ( 24 hours after distribution) were weighed daily. The Dry Matter of distributed and refused feed was determined by evaporation at $105^{\circ} \mathrm{C}$ for $48 \mathrm{~h}$ on a drying oven. Apparent digestibility coefficient (ADC) of dry matter (DM) was calculated by the following formula.

$\mathbf{A D C}=(\mathbf{I}-\mathbf{M}) / \mathbf{I} \times \mathbf{x} 100$ with I: dry matter intake and $\mathrm{M}$ : dry matter manure issued.

\section{Evaluation of hematological and biochemical parameters}

$4 \mathrm{ml}$ of blood samples were collected from 4 chickens per group at the wing vein using using a syringe. (VENOJECT ${ }^{\circledR}$, 22 gauge). Samples were taken at the end of experiment on 56 day of age. The blood was collected in two tubes: one with EDTA (ethylene - diamine - tetra acetic - acid) and the other without anticoagulant respectively for hematological and biochemical analysis. These parameters were evaluated at the Laboratory for Research in Applied Biology of University of Abomey-Calavi. These following biochemical constants were analyzed: glucose, cholesterol and creatinin levels. Blood glucose was determined according to the method described by Aslam et al. (2010). The creatinin assay was conducted by the kinetic method of Jaffe (Junge et al. 2004). The cholesterol was assayed by the enzymatic method described by Aslam et al. (2010). For the hematological parameters, number of red blood cells (RBC), white blood cell count (WBC), Hemoglobin (Hb), Hematocrit (Ht), Mean Corpuscular Volume (MCV), Mean Corpuscular Hb levels (MCH) and Mean Corpuscular Hemoglobin Concentration (MCHC) were determined. This assessment was made by introducing the blood sample in a hematology analyzer (nicros - ABX) for the analysis of parameter.

\section{Statistical Analyses}

The SAS software (Statistical Analysis System, 2006) was used for data analysis. The sources of variation were the dose and duration. The Proc GLM (General Linear Model) procedure was used for the analysis of variance. The $\mathrm{F}$ test was used to determine the significance of the effects of dose and duration. Means were compared pair wise by the t test.

\section{RESULTS}

\section{Main phyto-constituents of $C$. frutescens}

Table 2 shows the results of the phytochemical screening of the powder of $C$. frutescens. This screening shows that Capsicum frutescens powder used contains alkaloids, mucilage, reducing compounds, sterols and polyterpenes. Other compounds such as flavonoids, free and combined anthraquinones, tannins and leuco-anthocyanins and coumarins are absent.

Table 2: Phytochemical composition of $C$. frutescens fruit.

\begin{tabular}{lll}
\hline Phytochemical constituant & Results \\
\hline Anthocyanins & - \\
Alkaloids & & + \\
Free anthraquinones & - \\
Combined anthraquinones & & - \\
Flavonoids & Gallic & - \\
Tanins & Catechin & - \\
& & + \\
Mucilages & - \\
Saponosides & + \\
Reducing compounds & - \\
Leuco-anthocyanins & - \\
Coumarins & + \\
Sterols and polyterpenes &
\end{tabular}

Zootechnical parameters of Hubbard broilers that were fed with $C$. frutescens powder

\section{Apparent digestibility of dry matter}

The results of the digestibility assay are presented in Table 3. The amount of dry matter intake was $97.28 \pm 1.30$ g.DM for the group P0, $97.24 \pm 1.30$ g.DM for chickens of group P5 which received supplementation of $0.5 \%$ chili powder and $99.95 \pm$ 1.30 g.DM for the group P10 (food plus $1 \%$ of the chilli powder). The quantity of manure produced was $25.61 \pm 1.30$ g.DM (P0), $25.62 \pm 1.30$ g.DM (P5) and $25.84 \pm 1.30$ g.DM for the group P10. The coefficient of apparent digestibility was: $73.72 \% \pm 1.28$ for Group P0; $73.55 \% \pm 1.28$ for group P5 and $74.95 \% \pm 1.28$ for P10. Statistical analyzes revealed no significant difference for these parameters among the different groups $(\mathrm{p}<0.05)$.

Table 3: Digestibility of dry matter

\begin{tabular}{lllll}
\hline Parameter & Groups & & $\begin{array}{l}\text { test of } \\
\text { signifiance }\end{array}$ \\
\cline { 2 - 5 } & P0 (control) & P5 & P10 & NS \\
\hline $\begin{array}{l}\text { Dry matter intake } \\
\text { g.DM) }\end{array}$ & $97.28 \pm 1.30^{\mathrm{a}}$ & $97.24 \pm 1.30^{\mathrm{a}}$ & $99.95 \pm 1.30^{\mathrm{a}}$ & $\mathrm{NS}$ \\
Manure (g.DM) & $25.61 \pm 1.30^{\mathrm{a}}$ & $25.62 \pm 1.30^{\mathrm{a}}$ & $25.04 \pm 1.30^{\mathrm{a}}$ & $\mathrm{NS}$ \\
ADC (\%) & $73.72 \pm 1.28^{\mathrm{a}}$ & $73.55 \pm 1.28^{\mathrm{a}}$ & $74.95 \pm 1.28^{\mathrm{a}}$ & $\mathrm{NS}$ \\
\hline
\end{tabular}

NS: Non Significant, P0: basal diet (BD) without chili powder (CP), P5: BD $+0.5 \% \mathrm{CP}$ or $5 \mathrm{~g}(\mathrm{CP}) / \mathrm{kg}$ diet; P10: $\mathrm{BD}+1 \% \mathrm{CP}$ or $10 \mathrm{~g}(\mathrm{CP}) / \mathrm{kg}$ diet; $\mathrm{ADC}=$ Apparent digestibility coefficient of dry matter; $\mathrm{DM}=$ Dry Matter. The means between the classes of the same line followed by same letter don't differ significantly with the threshold of $5 \%$.

\section{Food consumption, weight gain, average daily gain and feed conversion ratio of Hubbard broilers fed with $C$. frutescens powder}

Individual food consumption, the average final weight, Average Daily Gain (ADG) and feed conversion ratio (FCR) obtained at the end of the experiment are shown in Table 4. The feed intake did not change among the groups ( $p>0.05)$. It is the same for the average final weight, ADG and FCR, the respective values were similar from one treatment to another. Figure 1 shows the curve of 
the variation of the average weight of chickens in the time and according to different groups. At the beginning of the experiment, the average bird weight was $49.63 \pm 3.74 \mathrm{~g}$. At the end of the trial (day 56), the weight reached $1562.37 \pm 19.31 \mathrm{~g} ; 1525.11 \pm 19.31$ $\mathrm{g} ; 1605.80 \pm 19.31 \mathrm{~g} ; 1572.41 \pm 19.31 \mathrm{~g}$ and $157207 \pm 19.31 \mathrm{~g}$ respectively for P0; P5 , P5' , P10, and P10'. Throughout the test period, the average weight of the animals did not significantly varied from one group to another except at day $14(\mathrm{p}<0.01)$ and day 49 ( $\mathrm{p}<0.05$ ). On day 14, the groups P0 and P10' had similar average weights while the average weight of P5, P5' , and P10 are significantly lower than the control group but similar to average weight of P10'. At 49 days of age, compared with the control group, the average weight of the lot P5 is significantly lower but similar to the weight of a lot P5', P10 and P10' are also similar in their lot weight $\mathbf{P 0}$.

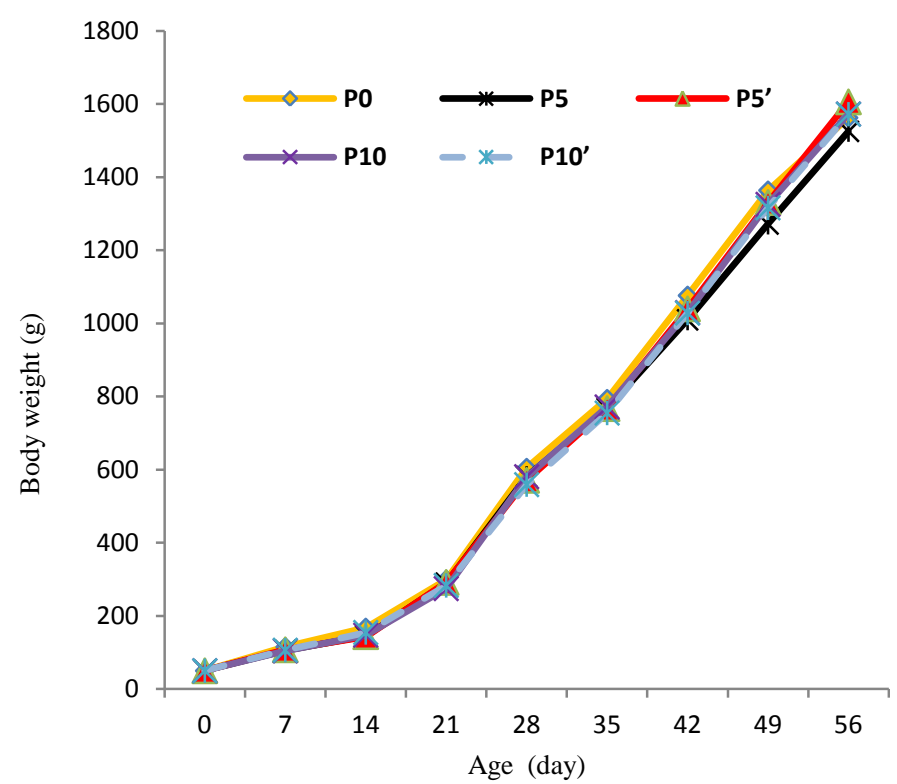

Fig. 1: Evolution of the average live weight of the various groups according to time.

Table 4: Performance of Hubbard broiler chicken fed diets containing various level of $C$. frutescens powder (0-56 day).

\begin{tabular}{|c|c|c|c|c|c|c|}
\hline \multirow[b]{2}{*}{ Parameters } & \multicolumn{5}{|l|}{ Group } & \multirow{2}{*}{$\begin{array}{l}\text { Test of } \\
\text { significance }\end{array}$} \\
\hline & P0 & P5 & P5' & P10 & P10' & \\
\hline \multirow{2}{*}{$\begin{array}{l}\text { Feed } \\
\text { consummation } \\
\text { (g.DM) }\end{array}$} & 3657.76 & 3592.62 & 3609.16 & 3610.25 & 3607.17 & \multirow[t]{2}{*}{ NS } \\
\hline & $\pm 28.30^{\mathrm{a}}$ & $\pm 28.30^{\mathrm{a}}$ & $\pm 28.30^{\mathrm{a}}$ & $\pm 28.30^{\mathrm{a}}$ & $\pm 28.30^{\mathrm{a}}$ & \\
\hline \multirow{2}{*}{$\begin{array}{l}\text { Initial } \\
\text { weight (g) }\end{array}$} & 49.63 & 49.63 & 49.63 & 49.63 & 49.63 & \multirow[t]{2}{*}{ NS } \\
\hline & $\pm 3.74^{\mathrm{a}}$ & $\pm 3.74^{\mathrm{a}}$ & $\pm 3.74^{\mathrm{a}}$ & $\pm 3.74^{\mathrm{a}}$ & $\pm 3.74^{\mathrm{a}}$ & \\
\hline \multirow{4}{*}{$\begin{array}{l}\text { Final weight } \\
\text { (g) } \\
\text { ADG }(g / j)\end{array}$} & 1562.37 & 1525.11 & 1605.80 & 1572.41 & 1572.07 & \multirow[t]{2}{*}{ NS } \\
\hline & $\pm 19.31^{\mathrm{a}}$ & $\pm 19.31^{\mathrm{a}}$ & $\pm 19.31^{\mathrm{a}}$ & $\pm 19.31^{\mathrm{a}}$ & $\pm 19.31^{\mathrm{a}}$ & \\
\hline & 27.01 & 26.35 & 27.79 & 27.19 & 27.18 & \multirow[t]{2}{*}{ NS } \\
\hline & $\pm 0.34^{\mathrm{a}}$ & $\pm 0.34^{\mathrm{a}}$ & $\pm 0.34^{\mathrm{a}}$ & $\pm 0.34^{\mathrm{a}}$ & $\pm 0.34^{\mathrm{a}}$ & \\
\hline \multirow[t]{2}{*}{ FCR (g.DM/g) } & 2.42 & 2.43 & 2.32 & 2.37 & 2.37 & \multirow[t]{2}{*}{ NS } \\
\hline & $\pm 0.04^{\mathrm{a}}$ & $\pm 0.04^{\mathrm{a}}$ & $\pm 0.04^{\mathrm{a}}$ & $\pm 0.04^{\mathrm{a}}$ & $\pm 0.04^{\mathrm{a}}$ & \\
\hline
\end{tabular}

NS: Non Significant, P0: basal diet (BD) without chili powder (CP), P5: BD $+0.5 \% \mathrm{CP}$ or $5 \mathrm{~g}(\mathrm{CP}) / \mathrm{kg}$ diet for a month; P5': BD + 0.5\% CP for two months; P10: BD + 1\% CP or $10 \mathrm{~g}(\mathrm{CP}) / \mathrm{kg}$ diet for a month; P10': $\mathrm{BD}+$ $1 \%$ CP for two months; DM = Dry Matter; ADG: Average Daily Gain; FCR: Feed Conversion Ratio. The means between the classes of the same line followed by same letter don't differ significantly with the threshold of 5\%.
Biochemical and hematological parameters in Hubbard broilers supplemented to Capsicum frutescens powder

Biochemical and hematological parameters fed in chicken supplemented to Capsicum frutescens powder are presented in Tables 5 and 6 . These parameters did not vary from one group to the next, except blood glucose concentration for biochemical parameters. Chickens fed only the basic food showed higher blood glucose level than those from other groups ( $p<$ 0.001). Regarding hematological parameters, only the number of leukocytes varied significantly and chickens in the control group (P0) presented a higher number of leukocytes $(\mathrm{p}<0.01)$ but similar to that of chickens group P10'.

Table 5: Biochemical parameters in Hubbard broilers supplemented to Capsicum frutescens powder.

\begin{tabular}{|c|c|c|c|c|c|c|}
\hline \multirow[t]{2}{*}{ Parameters } & \multicolumn{5}{|c|}{ Groups } & \multirow{2}{*}{$\begin{array}{l}\text { Test of } \\
\text { significance }\end{array}$} \\
\hline & $\overline{\mathbf{P 0}}$ & P5 & P5' & P10 & P10' & \\
\hline $\begin{array}{l}\text { Glycaemia } \\
\text { (mmol/l) }\end{array}$ & $\begin{array}{l}2.58 \\
\pm 0.02^{\mathrm{a}}\end{array}$ & $\begin{array}{l}2.00 \\
\pm 0.02^{\mathrm{b}}\end{array}$ & $\begin{array}{l}1.92 \\
\pm 0.02^{\text {bc }}\end{array}$ & $\begin{array}{l}1.92 \\
\pm 0.02^{\text {bc }}\end{array}$ & $\begin{array}{l}1.86 \\
\pm 0.02^{\mathrm{c}}\end{array}$ & $* * *$ \\
\hline $\begin{array}{l}\text { Creatinin } \\
(\mathrm{mg} / \mathrm{dl})\end{array}$ & $\begin{array}{l}0.32 \\
\pm 0.01^{\text {a }}\end{array}$ & $\begin{array}{l}0.32 \\
\pm 0.01^{\text {a }}\end{array}$ & $\begin{array}{l}0.32 \\
\pm 0.01^{a}\end{array}$ & $\begin{array}{l}0.32 \\
\pm 0.01^{a}\end{array}$ & $\begin{array}{l}0.30 \\
\pm 0.01^{\mathrm{a}}\end{array}$ & NS \\
\hline $\begin{array}{l}\text { Cholesterol } \\
(\mathrm{mmol} / \mathrm{l})\end{array}$ & $\begin{array}{l}3.96 \\
\pm 0.02^{\text {a }}\end{array}$ & $\begin{array}{l}3.94 \\
\pm 0.02^{\text {a }}\end{array}$ & $\begin{array}{l}3.98 \\
\pm 0.02^{a}\end{array}$ & $\begin{array}{l}4.02 \\
\pm 0.02^{a}\end{array}$ & $\begin{array}{l}3.98 \\
\pm 0.02^{\mathrm{a}}\end{array}$ & NS \\
\hline
\end{tabular}

NS: Non Significant ( $>>0.05)$; ***: $\mathrm{p}<0.001$. P0: basal diet (BD) without chili powder (CP), P5: BD + $0.5 \% \mathrm{CP}$ or $5 \mathrm{~g}(\mathrm{CP}) / \mathrm{kg}$ diet for a month; P5': $\mathrm{BD}+0.5 \% \mathrm{CP}$ for two months; P10: $\mathrm{BD}+1 \% \mathrm{CP}$ or $10 \mathrm{~g}(\mathrm{CP}) / \mathrm{kg}$ diet for a month; P10': BD + 1\% CP for two months. The means between the classes of the same line followed by different letters differ significantly with the threshold of $5 \%$

Table 6: Hematological parameters in Hubbard broilers supplemented to Capsicum frutescens powder.

\begin{tabular}{|c|c|c|c|c|c|c|}
\hline \multirow{2}{*}{ Parameters } & \multicolumn{5}{|l|}{ Groups } & \multirow{2}{*}{$\begin{array}{l}\text { Test of } \\
\text { significance }\end{array}$} \\
\hline & $\overline{\mathbf{P 0}}$ & P5 & P5' & P10 & $\overline{\mathbf{P 1 0}}$ 'si & \\
\hline $\begin{array}{l}\text { Haematocrit } \\
(\%)\end{array}$ & $\begin{array}{l}38.08 \\
\pm 0.50^{a}\end{array}$ & $\begin{array}{l}37.42 \\
\pm 0.50^{a}\end{array}$ & $\begin{array}{l}37.86 \\
\pm 0.50^{a}\end{array}$ & $\begin{array}{l}38.06 \\
\pm 0.50^{\mathrm{a}}\end{array}$ & $\begin{array}{l}38.30 \\
\pm 0.50^{a}\end{array}$ & NS \\
\hline $\begin{array}{l}\text { Haemoglobin } \\
\text { (g/dl) }\end{array}$ & $\begin{array}{l}12.60 \\
\pm 0.07^{\mathrm{a}}\end{array}$ & $\begin{array}{l}12.76 \\
\pm 0.07^{\text {a }}\end{array}$ & $\begin{array}{l}12.70 \\
\pm 0.07^{\mathrm{a}}\end{array}$ & $\begin{array}{l}12.82 \\
\pm 0.07^{\mathrm{a}}\end{array}$ & $\begin{array}{l}12.80 \\
\pm 0.07^{\text {a }}\end{array}$ & NS \\
\hline $\begin{array}{l}\text { Leukocytes } \\
\left(10^{3} / \mathrm{ml}\right)\end{array}$ & $\begin{array}{l}25.22 \\
\pm 0.43^{\mathrm{a}}\end{array}$ & $\begin{array}{l}23.26 \\
\pm 0.43^{b}\end{array}$ & $\begin{array}{l}23.20 \\
\pm 0.43^{b}\end{array}$ & $\begin{array}{l}22.78 \\
\pm 0.43^{b}\end{array}$ & $\begin{array}{l}24.40 \\
\pm 0.43^{\mathrm{ab}}\end{array}$ & $* *$ \\
\hline $\begin{array}{l}\text { Red Blood } \\
\text { cells }\left(10^{3} / \mathrm{ml}\right)\end{array}$ & $\begin{array}{l}2980 \\
\pm 23.66^{\mathrm{a}}\end{array}$ & $\begin{array}{l}2940 \\
\pm 23.66^{\mathrm{a}}\end{array}$ & $\begin{array}{l}2960 \\
\pm 23.66^{\mathrm{a}}\end{array}$ & $\begin{array}{l}2960 \\
\pm 23.66^{\mathrm{a}}\end{array}$ & $\begin{array}{l}2940 \\
\pm 23.66^{\mathrm{a}}\end{array}$ & NS \\
\hline MCH ( pg) & $\begin{array}{l}42.28 \\
\pm 0.36^{\mathrm{a}}\end{array}$ & $\begin{array}{l}43.40 \\
\pm 0.36^{\mathrm{a}}\end{array}$ & $\begin{array}{l}42.91 \\
\pm 0.36^{\mathrm{a}}\end{array}$ & $\begin{array}{l}43.31 \\
\pm 0.36^{\mathrm{a}}\end{array}$ & $\begin{array}{l}43.54 \\
\pm 0.36^{\mathrm{a}}\end{array}$ & NS \\
\hline $\operatorname{MCHC}(\mathrm{g} / \mathrm{dl})$ & $\begin{array}{l}33.12 \\
\pm 0.45^{\text {a }}\end{array}$ & $\begin{array}{l}34.13 \\
\pm 0.45^{\text {a }}\end{array}$ & $\begin{array}{l}33.56 \\
\pm 0.45^{\mathrm{a}}\end{array}$ & $\begin{array}{l}33.69 \\
\pm 0.45^{\mathrm{a}}\end{array}$ & $\begin{array}{l}33.42 \\
\pm 0.45^{\mathrm{a}}\end{array}$ & NS \\
\hline MCV (fl) & $\begin{array}{l}127.85 \pm 2 \\
.16^{\mathrm{a}}\end{array}$ & $\begin{array}{l}127.34 \\
\pm 2.16^{\mathrm{a}}\end{array}$ & $\begin{array}{l}127.92 \\
\pm 2.16^{\mathrm{a}}\end{array}$ & $\begin{array}{l}128.61 \\
\pm 2.16^{\mathrm{a}}\end{array}$ & $\begin{array}{l}130.30 \\
\pm 2.16^{\mathrm{a}}\end{array}$ & NS \\
\hline
\end{tabular}

NS: Non Significant ( $>>0.05)$; **: $\mathrm{p}<0.01$. P0: basal diet (BD) without chili powder (CP), P5: BD + 0.5\% CP or $5 \mathrm{~g}(\mathrm{CP}) / \mathrm{kg}$ diet for a month; P5': BD $+0.5 \% \mathrm{CP}$ for two months; P10: $\mathrm{BD}+1 \% \mathrm{CP}$ or $10 \mathrm{~g}(\mathrm{CP}) / \mathrm{kg}$ diet for a month; P10': BD + 1\% CP for two months; MCV: Mean Corpuscular Volume, MCH: Mean Corpuscular Hb levels and MCHC : Mean Corpuscular Hemoglobin Concentration. The means between the classes of the same line followed by different letters differ significantly with the threshold of $5 \%$.

\section{DISCUSSION}

Phytochemical constituent of the $\boldsymbol{C}$. frutescens powder

The phytobiotics are commonly used in broiler breeding to improve growth performance and the quality and preservation of 
meat (Laurenson, 2002). The use of these phytobiotics in poultry is related to the wide variety of phyto-constituents responsible for their biological activities (Otunola et al., 2010). In this study, the phytochemical screening of $C$. frutescens fruit powder revealed the presence of alkaloids, mucilage, reducing compounds, sterols and polyterpenes while flavonoids, anthraquinones, tannins, leucoanthocyanins and coumarins are absent. The phytochemical screening results are consistent with those reported by Otunola et al. (2010) except that flavonoids which have been reported in the powder of Capsicum frutescens by these authors in Côte d' Ivoire. These authors reported no tannins, saponins and quinones. However, according to Otunola et al., (2010), the presence of tannins and saponins was noted in the same spice in Nigeria. These differences in the chemical composition of the powder of $C$. frutescens used in our study may be related to differences in agroecological zones in relation to climatic and environmental factors reported by Kubmarawa et al. (2007).

\section{Production parameters of broilers fed Hubbard powder $C$. frutescens}

The results obtained for the apparent digestibility test indicate that the chickens receiving supplementation C. frutescens ' powder showed similar digestibility relative to the control lot. This suggests that the different rates of incorporation of the powder of Capsicum frutescens did not significantly influenced the apparent digestibility of dry matter in broiler chickens. However, although there is no difference between groups for the ADC, chickens that received powder $C$. frutescens $1 \%$ showed a slightly higher than rations digestibility of the other lots. These results confirm the positive effect of $C$. frutescens on the digestibility reported by Hernandez et al. (2004). These authors reported that Capsicum frutescens contains capsaicin, which improves digestibility in broilers.

Zootechnical parameters did not significantly vary from one group to another. This suggests that, compared with the control group, supplementation of the food with the powder of Capsicum frutescens did not favor a fattening in broilers Hubbard. This is linked to the slimming effect of capsaicin (the main component of chili), reported by Ludy and Mattes (2011). Individual food consumption, the average final weight and average daily gain are low compared to those reported by Al- Kassie et al. (2011) in broilers. This difference is related to the variety of chilli used in this study. Indeed, Sanatombi and Sharma (2008) reported that $C$. frutescens contains more capsaicin with slimming effect than Capsicum annum used by these authors. This may explain the weak growth performance, $1525.11 \pm 19.31$ to $1605.80 \pm 19.31 \mathrm{~g}$ for example for the final body weight, obtained in this study compared to those , 2,375 \pm 23 to $2579 \pm 23 \mathrm{~g}$ (final body weight), reported by Atapattu and Belpagodagamage (2010).

\section{Evaluation of biochemical and hematological parameters of chickens fed with powdered Capsicum frutescens}

In the present study, blood glucose was influenced by the different rates of incorporation of the powder of Capsicum frutescens. It ranged from $2.58 \mathrm{mmol} / 1$ in the control group to $1.86 \mathrm{mmol} / 1$ for lot P10'. These values are below those reported by Al - Kassie et al. (2011) have reported that blood glucose levels ranging from $6.38 \mathrm{mmol} / \mathrm{l}$ to $8.14 \mathrm{mmol} / \mathrm{l}$. This difference is related to the variety of chilli used in this study. The incorporation of chilli powder in the staple significantly reduced blood sugar levels in broilers. This hypoglycemic effect of pepper has been reported by Al- Kassie et al. (2011) in broiler chickens fed different levels of incorporation of Capsicum annum, by Tolan et al. (2001) in canines and humans by Al- Kassie et al. (2011). Capsaicin which is the main component of chilli inhibits the intestinal absorption of glucose and this justifies the hypoglycaemic effect of chilli as pointed by Al- Kassie et al. (2011). It should be noted that in this study, the duration of supplementation had no effect on this parameter as biochemical chickens receiving supplementation for two months showed almost similar to that of glucose chickens were treated for one month.

As regards the other biochemical parameters, creatinin and cholesterol, the influence of Capsicum frutescens was not remarkable. Indeed, the values obtained for cholesterol level in our study are close to $3.98 \mathrm{mmol} / \mathrm{l}(155.1 \mathrm{mg} / \mathrm{dl})$ obtained by Eldeeb et al. (2006) in broilers that received supplementation of Capsicum frutescens $150 \mathrm{ppm}$. These results, however, are contrary to those obtained by Atapattu and Belpagodagamage (2010) who observed a hypo- cholesterolemic effect of Capsicum annum powder incorporated at $1 \%$ in the staple. Similarly, Al-Kassie et al. (2011) showed a reduction of cholesterol levels in broilers that received different doses of supplementation in Capsicum annum. The variety of chilli and environmental factors are the basis for this variation.

The rate of creatinin, no difference was observed in chickens of different group, this suggests the safety of Capsicum frutescens on renal function. According Aslam et al. (2010), an increase in serum creatinine is indicative of poor renal function.

The values of various hematological parameters in this study, except hematocrit, are consistent with the standards and reported by Bell and Sturkie (2000) and in chickens that are $20-30 \times 10^{3} / \mathrm{ml}$ for leukocytes; $2500-3500 \times 10^{3} / \mathrm{mL}$ for red blood cells from 33 to $47 \mathrm{pg}$ for MCH; 26-35g/dl and for MCHC 90-143 fl for MCV. The incorporation of chili powder in the feed had no effect on hematological parameters outside the number of leukocytes which was relatively lowest in chickens treated. The different values obtained regarding the hematocrit and hemoglobin concentration are higher than those reported by Al - Kassie et al. (2011). Indeed, hemoglobin and hematocrit, respectively ranged from 7.45 to 8.73 $\mathrm{g} / \mathrm{dl}$ and 24.2 to $27.3 \%$. However, for the number of red blood cells, the values reported by these authors are higher than ours. These differences may be related to experimental breed of chicken flesh. These authors used the Ross 308 broiler chickens unlike Hubbard selected for this study. According to Aslam et al. (2010), hematologic parameters of broilers may be influenced by genotype and environmental factors. The chemical composition of the variety of pepper used could also qualify these results. 


\section{CONCLUSION AND SUGGESTIONS}

Supplementation of the food with Capsicum frutescens powder had no noticeable effect on weight gain and feed conversion ratio in Hubbard broilers. It is the same biochemical parameters outside the blood glucose level which declined at Hubbard broilers treated with the powder of this fruit. Hematological parameters were not changed either except the number of leukocytes. The powder of Capsicum frutescens did not influence characteristics and meat quality of broilers. Thus, this study allows us to conclude that the powder of $C$. frutescens cannot be used in order to improve the production performance of broilers Hubbard. However, the sample size may explain the results obtained with regard to the characteristics and quality of the carcass of broiler chickens. However, the fruit of this plant can be used to reduce blood glucose level.

\section{REFERENCES}

Al-Kassie GAM, Mamdooh AMA, Saba JA. The effects of using hot red pepper as a diet supplement on some performance traits in broiler. Pakistan Journal of Nutrition. 2011: 9, 842-845. DOI : 10.3923/pjn.2011.842.845

Aslam F, Khan A, Khan MZ, Sharaf S, Gul ST, Saleemi MK. Toxico-pathological changes induced by cypermethrin in broiler chicks: Their attenuation with Vitamin E and selenium. Experimental and Toxicologic pathology. 2010: 62 (4), 441-450. DOI : 10.1016/j.etp.2009.06.004

Atapattu NSBM, Belpagodagamage UD. Effect of dietary chilli powder on growth performance and serum cholesterol contents of broiler chicken. Tropical Agricultural Research \& Extension. 2010 : 13 (4), 106-109. DOI: http://dx.doi.org/10.4038/tare.v13i4.3294

Barreto MSR, Menton JFM, Racanicci AMC, Pereira PWZ. Plant extract used as growth promoter in broilers. Revista Brasileira de Ciência Avicola. 2008: 10, 109-115. DOI : http://dx.doi.org/10.1590/S1516$635 \times 2008000200006$

Bell DJ, Sturkie PD. Chemical constituents of Blood. In Avian Physiology. Edited by Paul D. Sturkie Comstock publishing associates a division of Cornell University Press, Ithaca, New York. 2000: p 32.

Feldman BF, Zinkl JG, Jain NC. Veterinary pathology. 2000: 5, 755-763. DOI :10.1354/vp.40-2-223
Hernandez F, Mardrid J, Garcia V, Orengo J, Megias MD. Influence of two plant ex-tracts on broiler performance, digestibility, and digestive organ size. Poultry Science. 2004: 83,169-174. DOI : 10.1093/ps/83.2.169

Houghton PJ, Raman A. 1998. Laboratory handbook for the fractionation of natural extracts, New York, Ed Chapman and Hall, p.208 DOI : 10.1007/978-1-4615-5809-5

Junge W, Wilke B, Halabi A, Klein G. Determination of reference intervals for serum creatinine, creatinine excretion and creatinine clearance with an enzymatic and a modified Jaffe method. Clinica Chimica Acta. 2004: 1, 137-148. DOI: 10.1016/j.cccn.2004.02.007

Kubmarawa D, Ajoku GA, Enwerem NM, Okori DA. Preliminary phytochemical and antimicrobial screening of 50 medicinal plants from Nigeria. African Journal of Biotochnology. 2007: 6 (14), 1690-1696. DOI : 10.5897/AJB2007.000-2246

Laurenson P. Détermination des paramètres zootechniques de la pintade locale dans la région du Borgou. Mémoire pour l'obtention du diplôme d'Ingénieur : Faculté des Sciences Agronomiques de Gembloux, Université de Gembloux. $2002: 81$ p.

Li, H, Jin L, Wu F, Thacker P, Li X, You J, Wang X, Liu S, Li S, $\mathrm{Xu}$ Y. Effect of red pepper (Capsicum frutescens ) powder, or red pepper pigment on the performance and egg yolk color of laying hens. AsianAustralasian Journal of Sciences. 2012: 25 (11), 1605-1610. DOI http://dx.doi.org/105713/ajas.2012.12235

Ludy MJ, Mattes R. The effects of hedonically acceptable red pepper doses on thermogenesis and appetite. Physiology and Behavior. 2011: 102, 251-258. DOI : 10.1016/j.physbeh.2010.11.018

Otunola GA, Oloyede OB, Oladiji AT, Afolayan AJ. Comparative analysis of the chemical composition of three spices- Allium sativum L., Zingiber officinale Rosc and Capsicum frutescens L. commonly consumed in Nigeria. African Journal of Biotochnology. 2010: 9 (41), 6927-6931. DOI: 10.5897/AJB10.83

Sanatombi K, Sharma GJ. Capsaicin content and pungency of different Capsicum spp. cultivars. Notulae Botanicae Horti Agrobotanici ClujNapoca. 2008 : 36 (2), 89-90. DOI: 10.1155/2012/873090

Tolan I, Ragoobirsingh D, Morrison EY. The effect of capsaicin on blood glucose, plasma insulin levels and insulin binding in dog models Phytotherapy Research. 2001: 15 (5), 391-394. DOI: 10.1002/ptr.750

\section{How to cite this article:}

Dougnon T.J., Kiki P., Dougnon T.V., Youssao I. Evaluation of Capsicum frutescens powder effects on the growth performances, biochemical and hematological parameters in Hubbard broiler. J App Pharm Sci, 2014; 4 (10): 038-043. 